\title{
PEREMPUAN DALAM POLITIK DI SULAWESI UTARA
}

\author{
Leviane Jackelin Hera Lotulung ${ }^{1}$ dan Deddy Mulyana ${ }^{2}$ \\ ${ }^{1}$ Jurusan Ilmu Komunikasi, Fakultas Ilmu Sosial dan Politik, Universitas Sam Ratulangi, Manado. \\ ${ }^{2}$ Fakultas Ilmu Komunikasi Universitas Padjadjaran Bandung \\ E-mail: jackelin.lotulung@unsrat.ac.id
}

\begin{abstract}
ABSTRAK. Pasca reformasi, tren kenaikan angka partisipasi perempuan dalam politik di DPRD Provinsi Sulawesi Utara semakin nyata. Hal itu didukung oleh peraturan perundang-undangan yang mendorong keterlibatan perempuan dalam segala sektor kehidupan. Dalam penelitian ini, peneliti ingin mencari tahu faktor lainnya yang mendukung perempuan Sulawesi Utara bisa begitu mudah masuk dunia politik. Metode penelitian menggunakan pendekatan studi kasus dengan wawancara mendalam, pengamatan lapangan, serta studi literatur. Informannya adalah sebelas legislator perempuan di DPRD Provinsi Sulawesi Utara dan beberapa. Hasilnya ditemukan beberapa faktor sehingga perempuan Sulawesi Utara masuk dunia politik. Faktor-faktor tersebut yakni dukungan perundang-undangan di bidang politik, faktor sosial budaya, bahkan agama dan kedekatan calon legislator perempuan dengan pimpinan partai dan penguasa. Nama keluarga yang melekat pada nama belakang perempuan sebagai salah satu ciri budaya patriarkhi, baik yang berasal dari nama ayah maupun suami yang popular secara politik, menjadi modal tersendiri guna memperlancar perempuan masuk dunia politik.
\end{abstract}

Kata kunci: perempuan, gender, politik, patriarkhi.

\section{WOMEN IN POLITICS IN NORTH SULAWESI}

\begin{abstract}
Post reformation, the trend of inreasing participation number of women in politics in DPRD North Sulawesi Province more real. This is supported by legislation that encourages the involvement of women in all sectors of life. In this study, researchers want to find out other factors that support women of North Sulawesi could easily join the politics. The research method used is the case study approach by using in-depth interview, field observation, and literature study. The informants were eleven female legislators in North Sulawesi DPRD and several academics. The result found several factors so that women of North Sulawesi join the political world. These factors are legislative support in the field of politics, socio-cultural factors, even religion and the proximity of women legislator candidates with party leaders and rulers. The name of the family attached to the last name of women as one of the characteristics of patriarchal culture, whether it comes from the name of father or husband who is politically popular, became a separate capital to facilitate women to join politics.
\end{abstract}

Key words: women, gender, politics, patriarchy.

\section{PENDAHULUAN}

Indonesia sebagai negara yang berlatar belakang beragam suku bangsa, bahasa, dan agama memiliki beragam perlakuan pula terhadap perempuan dan lakilaki. Perempuan selalu ditempatkan pada kegiatankegiatan domestik sedangkan laki-laki pada kegiatan publik termasuk di bidang politik. Perbedaan antara lakilaki dan perempuan di masyarakat akhirnya diperjuangkan perempuan sehingga pada akhirnya mendorong pemerintah mengeluarkan beberapa aturan untuk menjamin persamaan hak dan kewajiban antara laki-laki dan perempuan atau kesetaraan gender. Padahal secara hakiki pemerintah Indonesia telah mengakui bahkan menjamin kesetaraan antara laki-laki dan perempuan di segala bidang kehidupan, sebagaimana tercantum dalam Undang-undang Dasar 1945 dalam Pasal 27 ayat 1, "Segala warga negara bersamaan kedudukannya di dalam hukum dan pemerintahan dan wajib menjunjung hukum dan pemerintahan itu dengan tidak ada kecualinya".

Undang-undang Dasar 1945 itu ternyata tidak cukup sehingga Indonesia meratifikasi Deklarasi Universal Hak Asasi Manusia, Konvensi mengenai Penghapusan Hak Segala Bentuk Diskriminasi Terhadap Perempuan (Convention on The Elimination of All Forms of Discrimination Against Women-CEDAW) yang disah- kan melalui Undang-undang Nomor 7 Tahun 1984 tentang Ratifikasi Konvensi Penghapusan Segala Bentuk Diskriminasi terhadap perempuan. Pasal 4 ayat 1 UndangUndang ini memberikan kewajiban kepada negara untuk menyusun peraturan khusus demi mempercepat kesetaraan gender antara laki-laki dan perempuan. Demikian pula Undang-Undang Nomor 39 Tahun 1999 Pasal 46 tentang Hak Asasi Manusia (HAM) menyatakan bahwa sistem pemilihan umum, kepartaian, pemilihan anggota badan legislatif, dan sistem pengangkatan di bidang eksekutif dan yudikatif harus menjamin keterwakilan perempuan sesuai dengan persyaratan yang ditentukan. (Amalia dalam Amalia, 2012:238)

Aturan hukum tersebut juga diperkuat dengan Instruksi Presiden (Inpres) Nomor 9 Tahun 2000 tentang Pengarusutamaan Gender dalam Pembangunan Nasional. Inpres ini (Amalia, 2012) merumuskan pengarusutamaan gender sebagai suatu strategi untuk mencapai kesetaraan dalam keadilan gender melalui kebijakan dan program yang memperhatikan pengalaman, aspirasi, kebutuhan, dan permasalahan perempuan dan laki-laki ke dalam proses perencanaan, pelaksanaan, pemantauan, dan evaluasi atas seluruh kebijakan dan program di berbagai bidang kehidupan dan sektor pembangunan.(Amalia, 2012:238-239) 
Dengan adanya dasar hukum tersebut, sangat terbuka peluang bagi perempuan untuk bisa eksis dalam seluruh komponen kehidupan berbangsa dan bernegara termasuk mengabdi di bidang politik dan pemerintahan. Namun sangat disadari bahwa ada rintangan-rintangan secara budaya yang masih menjadi halangan terberat bagi perempuan untuk masuk pada bidang politik dan pemerintah.

Sejarah perbedaan gender antara pria dengan perempuan terjadi melalui proses yang sangat panjang dan dibentuk oleh beberapa sebab, seperti faktor sosial budaya, faktor agama, dan faktor politik. Dengan proses yang panjang ini, perbedaan gender akhirnya sering dianggap menjadi ketentuan Tuhan yang bersifat kodrati atau seolah-olah bersifat biologis yang tidak dapat diubah lagi. Inilah sebenarnya yang menyebabkan awal terjadinya ketidakadilan gender di tengah-tengah masyarakat.

Konsep gender menurut Fakih (2010:8) adalah suatu sifat yang melekat pada kaum laki-laki maupun perempuan yang dikonstruksi secara sosial maupun kultural. Julia Cleves Mosse (2010:3) berpendapat bahwa gender adalah sebuah istilah yang menunjukkan pembagian peran sosial antara laki-laki dan perempuan dan ini mengacu kepada pemberian ciri emosional dan psikologis yang diharapkan oleh budaya tertentu disesuaikan dengan fisik laki-laki dan perempuan.

Dari ajaran-ajaran agama diperoleh gambaran bahwa laki-laki dan perempuan memiliki kedudukan yang sama. Dalam ajaran agama Kristen, pada Kitab Kejadian pasal 1 ayat 26-27 dan 31 a, secara jelas ditentukan bahwa:

Berfirman Allah: "Baiklah Kita menjadikan manusia menurut gambar dan rupa Kita, supaya mereka berkuasa atas ikan-ikan di laut dan burung-burung di udara dan atas ternak dan atas seluruh bumi dan atas segala binantang melata yang merayap di atas bumi. Maka Allah menciptakan menurut gambar Allah diciptakan-Nya dia; laki-laki dan perempuan diciptakan-Nya mereka. Maka Allah melihat segala yang dijadikan-Nya sungguh amat baik.

Terkait Firman Tuhan itu, maka menurut Stefania Cartore (dalam Sulistyowati Irianto, 2006), diwahyukan bahwa:

1. Laki-laki dan perempuan diciptakan sebagai hasil keputusan yang khusus dari Allah;

2. Laki-laki dan perempuan, merupakan makhluk yang berasal dari Allah yang satu dan sama; Khalik mereka;

3. Laki-laki dan perempuan, entah bersama-sama atau secara terpisah, memiliki kesempurnaan dengan Allah. Sebagai gambar Allah, baik laki-laki maupun perempuan, mereka dimungkinkan untuk (1) berelasi dengan Allah sebagai orang tua (parent), denganNya, mereka memiliki "keserupaan" (2) bertindak menurut teladan-Nya (3) melanjutkan karya penciptaanNya, entah melalui eksistensi manusia yang lain atau dengan memelihara dunia ciptaannya;
4. Laki-laki dan perempuan memiliki martabat yang sama dalam segala aspeknya. Martabat mereka didasarkan pada "keserupaan" mereka dengan Allah yang mendorong mereka dengan Allah yang mendorong mereka untuk dapat melampaui apa yang dapat mereka capai dan "mendekati" apa yang telah direncanakan Allah bagi hidup mereka.

Penjelasan di atas sangat membantu kita untuk memahami bahwa manusia (perempuan dan laki-laki) memperoleh pandangan yang sama, status yang sama dan juga peran yang sama.

Dalam ajaran agama Islam tertuang juga hal serupa bahwa antara laki-laki dan perempuan adalah sama di mata Allah. Sebagaimana yang telah dijelaskan Allah dalam Surat Al-Hujurat 13:

Hai manusia sesungguhnya Kami menciptakan kamu dari seorang laki-laki dan seorang perempuan, dan menjadikan kamu berbangsa-bangsa dan bersukusuku supaya kamu saling mengenal. Sesungguhnya orang yang paling mulia di sisi Allah adalah yang paling bertaqwa di antara kamu. Sesungguhnya Allah Maha Mengetahui lagi Maha Mengenal.

Dengan demikian tidak ada perbedaan antara laki-laki dan perempuan sebagai manusia. Berkaitan dengan itu al-Qur'an sebagai rujukan dan prinsip dasar menjelaskan bahwa kedudukan laki-laki dan perempuan diakui secara adil dan non-diskriminatif, dalam uraian di hadapan Allah mereka itu sama, kecuali taqwa.

Lebih jauh Nasaruddin Umar (dalam Hulwati 1999:248) mengungkapkan bahwa dalam kapasitasnya sebagai hamba tidak ada perbedaan antara laki-laki dan perempuan. Kedua-duanya mempunyai potensi serta peluang yang sama untuk menjadi ideal sehingga mereka dapat bergerak dalam berbagai bidang, lengkap dengan beberapa keistimewahan, dan kelebihan sesuai dengan fitranya.

Dengan melihat uraian di atas mengenai kesetaraan antara laki-laki dan perempuan dari kacamata ajaran agama, kemudian peneliti berpandangan bahwa pada dasarnya tidak ada perbedaan antara laki-laki dan perempuan. Perempuan punya hak-hak yang sama dengan lakilaki di bidang politik, pendidikan, kerja dan ini ditempuh melalui jalur hukum dengan cara mereformasi sistem yang ada.

Praktek perbedaan gender juga terjadi di Indonesia, dimana perempuan lebih diarahkan pada kegiatankegiatan domestik, sedangkan kegiatan publik lebih diarahkan kepada kaum laki-laki. Meski begitu, Provinsi Sulawesi Utara, salah satu provinsi di Indonesia dengan partisipasi perempuan dalam bidang politik cukup maju dilihat dari keterwakilan perempuan di legislatif maupun di eksekutif. Hal itu sesuai dengan Indeks Pembangunan Gender (IPG) Kementerian Pemberdayaan Perempuan dan Perlindungan Anak tahun 2016 bahwa Sulawesi 
Utara menjadi provinsi tertinggi ketiga setelah Provinsi Sumatera Barat dan DKI Jakarta (Kemen PP dan PA, 2016:49).

Tabel 1. Keterwakilan Perempuan Sulawesi Utara di DPRRI, DPD-RI dan DPRD Provinsi di Era Reformasi

\begin{tabular}{cccc}
\hline Periode & DPR- RI & DPD RI & DPRD Provinsi \\
\hline $1999-2004$ & - & - & $7(15,56 \%)$ \\
$2004-2009$ & - & $2(50 \%)$ & $8(17,77 \%)$ \\
$2009-2014$ & $2(50 \%)$ & $1(25 \%)$ & $12(26,66 \%)$ \\
$2014-2019$ & $2(50 \%)$ & $2(50 \%)$ & $15(33,33 \%)$ \\
\hline
\end{tabular}

Sumber: Data berasal dari KPU Sulawesi Utara diolah peneliti

Dari tabel di atas terlihat ada kecenderungan positif dan naik dari peran perempuan dalam politik sebagai legislatior baik tingkat DPR, DPD, maupun DPRD Provinsi dari periode ke periode selama era reformasi. Ini berbeda dengan kondisi secara nasional keterwakilam perempuan pada dunia politik di DPR RI yang masih rendah sesuai data KPU RI Pemilu 2014 legislator perempuan hanya 97 orang dari jumlah keseluruhan 560 legislator atau hanya 17,32 persen saja (Kemen PP dan PA, 2016:65).

Penelitian-penelitian mengenai gender dan keberadaannya diranah publik sudah sering dilakukan, antara lain oleh Widayani dan Hartati (2014) dengan informan para penulis perempuan di Bali tentang kesetaraan dan keadilan gender pada budaya Bali yang patriarki. Ditemukan dua faktor atas pengalaman perempuan Bali mengenai kesetaraan dan keadilan gender yakni faktor eksternal atau situasional yang mencakup kebudayaan Bali,pendidikan, dan polaasuh. Kedua, faktorinternalyang meliputi persepsi, sikap, penilaian, kebutuhan, resistensi, dukungan sosial, penyesuaian diri, beliefs dan future expection. Hulwati (1999) membahas perempuan dalam wacana politik Islam menemukan bahwa perempuan sebagai hamba Allah yang mempunyai tanggung jawab untuk memakmurkan bumi. Karena itu perempuan mempunyai hak dan kewajiban yang sama dengan lakilaki dalam Islam dan dapat mengaktualisasikan dirinya di tengah masyarakat.

Sinulingga (2006) yang menggali penelitian gender ditinjau dari sudut pandang agama Kristen menemukan ada dua makna gender. Pertama, mengikuti budaya (yang dipengaruhi konteks tempat dan waktu), kedua, gender yang lepas dari budaya. Dalam Alkitab terutama Perjanjian Lama, pemahaman gender tidak lepas dari pengaruh budaya. Situasi sosial budaya yang berubahubah menghasilkan gambaran tentang status dan peranan laki-laki dan perempuan yang berubah-ubah. Sementara makna gender yang lepas dari budaya, memperlihatkan status dan peran laki-laki dan perempuan yang ideal yang mengajarkan kesetaraan dan keadilan gender. Sedangkan ketidakadilan gender yang tertulis dalam Alkitab sebagai pengaruh sosial budaya yang panjang yang harus dipelajari latar belakangnya dan tujuan penulisannya sehingga dapat ditemukan pengajarannya untuk masa lalu dan masa kini.
Farida (2013) menggali peluang perempuan dalam birokrasi pemerintahan Kota Bandar Lampung sehingga perlu dilakukan rekruitmen, seleksi, pendidikan, dan pelatihan guna meningkatkan pelayanan publik di pemerintahan kota. Dalam penelitian tersebut, Farida menemukan bahwa manajemen SDM (perekruitan, seleksi, pendidikan, dan pelatihan) birokrat perempuan di lingkungan pemerintahan Kota Bandar Lampung tergolong baik, artinya secara keseluruhan, pengembangan pegawai perempuan sudah dilakukan sesuai standar yang berlaku, walaupun dalam beberapa tingkat tertentu masih dianggap menghambat pengembangan pegawai yang sifatnya lebih pribadi ketimbang administratif atau organisasional. Aspek rekruitmen merupakan aspek yang penting dalam menentukan tingkat partisipasi pegawai perempuan untuk bekerja dan berhubungan dengan masyarakat guna menghasilkan pelayanan publik yang baik.

Sisi otonomi daerah dan komunikasi politik perempuan, Wahid (2014) menemukan masih banyak tantangan yang dihadapi perempuan saat itu, guna menjadi kandidat perempuan di parlemen Provinsi DKI Jakarta tahun 2009. Ditemukan ketentuan affirmative action 30 persen harus lebih berkembang dengan diberlakukannya UU Otonomi Daerah. Otonomi daerah belum mampu meningkatkan keterwakilan perempuan di politik dikarenakan munculnya kelompok-kelopok masyarakat dan pemerintahan yang kurang mendukung pemberdayaan perempuan di politik. Partai politik sendiri belum mendukung pelaksanaan kuota secara menyeluruh, namun hanya mendukung sebagai ketentuan Undangundang Partai Politik 2008 dalam penentuan calon anggota legislator DKI Jakarta pada Pemilu 2009. Hal itu dilihat dari ketidaksiapan partai politik dalam menentukan calon legislator perempuannya. Media massa juga tidak berperan sebagai starting point yang melahirkan ide, melainkan hanya memainkan peran sebagai fenomena picker yang berlandaskan pada kepentingannya sendiri. Media menjadi miskin ideologi yang berkaitan masalah gender. Sebuah peristiwa dipandang oleh media hanya sebagai objek berita yang hanya akan dimuat jika dianggap dapat memenuhi rasa keingintahuan publik sehingga laku dijual. Kaum perempuan membutuhkan ideologi yang komunal untuk menjamin kontinuitas perjuangan yang belum selesai, dan ideologi yang ditawarkan adalah colletive will. Tujuannya untuk mendapat dukungan media massa guna meraih posisi tawar calon legislator perempuan terhadap ideologi dominan negara. Terakhir, diperlukan perjuangan lebih keras dan terus menerus dari kaum perempuan dalam bidang politik maupun ruang publik lainnya sebagai bentuk counter hegemony terhadap masyarakat politik yang korup dan tidak adil.

Penelitian-penelitian di atas akhirnya mengarahkan peneliti untuk melihat makna dari kenaikan angka partisipasi perempuan dalam politik di DPRD Provinsi Sulawesi Utara sebesar 33,3 persen atau tertinggi di antara seluruh DPRD Provinsi di Indonesia. Dengan 
alasan itu akhirnya peneliti mencari tahu faktor-faktor apa saja yang mendukung perempuan sehingga bisa eksis di dunia politik Sulawesi Utara.

\section{METODE}

Keterlibatan perempuan Sulawesi Utara masuk dunia politik cukup memadai. Ini merupakan hal yang positif bagi kemajuan kesetaraan gender di Indonesia. Penelitian ini menggunakan metode studi kasus yang menurut hemat peneliti adalah metode yang tepat yang ditandai dengan kekhasan dan keunikan dari fenomena yang diteliti.

Studi kasus merupakan penelitian yang berusaha untuk mengali suatu batasan yang jelas, data yang mendalam disertai berbagai sumber informasi yang akurat. Dengan tujuannya untuk mendeskripsikan dengan utuh dan mendalam dari sebuah entitas (Mujahidin, 2014:126). Data-data dari metode studi kasus bisa menggunakan berbagai sumber data yang bisa menguraikan, dan menjelaskan secara komprehensif berbagai aspek individu, kelompok, suatu program, organisasi atau peristiwa secara sistematis. (Kriyantono, 2010:65). Cresswell (2015:137) bahkan mengutarakan studi kasus memiliki ciri utama yakni dengan memperlihatkan pemahaman mendalam tentang kasus tersebut. Seperti naiknya angka partisipasi perempuan di DPRD Provinsi Sulawesi Utara pada periode 2014-2019 menjadi capaian yang tertinggi secara prosentase di antara seluruh DPRD provinsi di Indonesia.

Mulyana (2010:201) pun menjelaskan peneliti studi kasus berupaya menelaah sebanyak mungkin data mengenai subjek yang diteliti. Penelitian ini menggali informasi mendalam mengenai dukungan perundangundangan atas perempuan, keadaan sosial budaya juga faktor agama yang mempengaruhi keberadaan perempuan dalam politik di Provinsi Sulawesi Utara. Penelitian ini dilakukan dari tahun 2016 dan 2017. Informannya adalah sebelas legislator perempuan yang terpilih sejak awal periode 2014-2019. Penelitian ini juga menggunakan kajian literatur untuk mendukung hasil yang ada.

\section{HASIL DAN PEMBAHASAN}

\section{Faktor Aturan}

Masa reformasi, keberpihakan pada perempuan untuk masuk politik semakin nyata dengan keluarnya berbagai perundang-undangan. Pertama, peluang perempuan untuk masuk dalam partai politik semakin besar dengan pola multi partai yang diterapkan. Pola peserta Pemilu tiga partai politik pun ditinggalkan. Kedua, ketentuan affirmative action terhadap perempuan dalam bidang politik dengan disahkannya UU Nomor 12 Tahun 2003 tentang Pemilu DPR, DPD, dan DPRD. Pasal 65 ayat 1 menyatakan: "Setiap partai politik peserta Pemilu dapat mengajukan calon anggota DPR, DPRD Provinsi, dan DPRD Kabupaten/Kota untuk setiap daerah pemilihan denganmemperhatikanketerwakilan perempuan sekurang- kurangnya $30 \%$ ". Tidak sampai di situ pemerintah juga mengatur kewajiban partai politik menyertakan keterwakilan perempuan minimal $30 \%$ dalam pendirian maupun dalam kepengurusan di tingkat pusat. UU Nomor 2 Tahun 2008 tentang Partai Politik yang mengatur syarat pendirian Partai Politik juga menyertakan keterwakilan perempuan 30\%. Kemudian terbitlah UU Nomor 10 Tahun 2008 tentang Pemilu Anggota DPR, DPD, dan DPRD. Pada Pasal 8 ayat (1) huruf d menyatakan bahwa "Partai politik dapat menjadi peserta Pemilu setelah memenuhi persyaratan menyertakan sekurang-kurangnya $30 \%$ (tiga puluh persen) keterwakilan perempuan pada kepengurusan partai politik di tingkat pusat". UU Nomor 8 Tahun 2012 tentang Pemilu yang kembali mengingatkan keterwakilan perempuan 30\% sebagai termuat Pasal 55 menyatakan "Daftar bakal calon sebagaimana dimaksud dalam Pasal 53 memuat paling sedikit 30\% (tiga puluh persen) keterwakilan perempuan. Ketiga, Undang-Undang Nomor 8 Tahun 2012 tentang Pemilu Anggota DPR, DPD, dan DPRD pada Pasal 56 ayat 2 yang menyatakan "Di dalam daftar bakal calon sebagaimana dimaksud pada ayat (1), setiap 3 (tiga) orang bakal calon terdapat sekurang-kurangnya 1 (satu) orang perempuan bakal calon."

Aturan-aturan tersebut mendorong perempuan calon legislator di Provinsi Sulawesi Utara berusaha sebaik mungkin dalam pelaksanaan kampanye dengan meyakinkan kepada para konstituen mengenai kemampuan dirinya sehingga layak dipilih. Kesempatan itu terus dibuktikan perempuan Sulawesi Utara, sehingga dari periode ke periode terlihat semakin signifikan keberadaannya di DPRD Provinsi Sulawesi. Periode 20142019 legislator yang terpilih sudah mencapai 15 personil (33\%) dari jumlah keseluruahan 45 personil sehingga capaian tersebut terbesar secara prosentase dibandingkan semua DPRD Provinsi di Indonesia. Bahkan angka itu semakin signifikan ketika terjadi penggantian antarwaktu akibat tiga legislator mengikuti Pilkada tahun 2015 dan satu legislator meninggal dunia. Jumlah legislator perempuan di DPRD Provinsi Sulawesi Utara sudah mencapai 17 personil dari 45 personil keseluruhan atau 37,7 persen.

\section{Faktor Sosial Budaya}

Provinsi Sulawesi Utara sama dengan provinsi lain di Indonesia, namun Sulawesi Utara memiliki keunikan tersendiri menyangkut eksistensi dan partisipasi politik kaum perempuannya. Perempuan Sulawesi Utara tidak banyak mengalami hambatan budaya ataupun sosial dalam persamaan hak dengan kaum pria di sektor publik. Hal itu terjadi karena Provinsi Sulawesi Utara didominasi budaya Minahasa lebih menganut budaya egaliter. Provinsi Sulawesi Utara sendiri sekarang terdiri dari empat suku bangsa, yakni Minahasa, Bolaang Mongondow, Sangihe, dan Talaud.

Keberadaan perempuan dalam kehidupan masyarakat di tanah Minahasa tidak dipandang sebelah mata 
malah menjadi ujung tombak bahkan turut menjadi penentu kebijakan untuk masa depan. Laki-laki dan perempuan membawa nama ayah sebagai petanda asalusul keluarganya yang dinamai fam. Namun khusus perempuan nama keluarga (fam) akan terhenti ketika perempuan menikah dan kemudian nama keluarga suamilah yang menjadi nama keluarga selanjutnya. Meski begitu budaya Minahasa tidak mengenal perbedaan dalam pembagian warisan antara laki-laki dan perempuan, semua tergantung kesepakatan dan keinginan pemberi warisan.

Dalam praktek politik di Sulawesi Utara nama keluarga (fam) yang punya latar belakang politik misalnya pimpinan partai ataupun mantan pimpinan partai, sangat berpengaruh untuk keberhasilan anak, isteri, kakakadik, keponakan, besan juga iparnya. Seperti di DPRD Provinsi Sulawesi Utara sebelas dari 15 legislator yang terpilih sejak awal periode sangat terkait dengan penguasa dan pimpinan partai. Hal itu ada hubungannya dengan budaya politik dari Lucian W. Pye yaitu sistem politik yang kemudian menjadi isu-isu politik yang terkait dengan sikap-sikap, kepercayaan, emosi dan nilai-nilai masyarakat. Keterkaitan calon legislator perempuan juga legislator perempuan dengan nama penguasa dan pimpinan politik merupakan keunggulan sebagai modal awal dalam keberhasilannya di politik (Alfian 2018:50).

Dalam masyarakat Sulawesi Utara, ada pemahaman positif terkait kesetaraan gender antara laki-laki dan perempuan di bidang publik. Menurut hemat peneliti, hal itu terjadi karena pengaruh agama Ktisten yang kuat di sana. Jika pada agama lain, pemimpin umat mayoritas laki-laki, sebaliknya di Kristen ada kesetaraan antara pemimpin umat lali-laki dan perempuan. Sebagai contoh, organisasi kekristenan terbesar di Sulawesi Utara, Gereja Masehi Injili di Minahasa (GMIM) malah didominasi oleh pendeta perempuan. Menurut Laporan Badan Majelis Sinode GMIM pada Sidang Majelis Sinode GMIM ke79 yang digelar pada 19-23 Maret 2018, pendeta GMIM tercatat berjumlah 2.218 orang yang terdiri dari pendeta perempuan 1.547 orang $(69,75 \%)$ dan pendeta laki-laki 671 orang $(30,35 \%)$.

Data ini memperlihatkan partisipasi perempuan di sektor publik, tidak saja telah didukung dari segi sosial budaya, tetapi juga didukung dari sisi agama. Perempuan tidak hanya didorong untuk bisa menjadi pemimpin agama, tetapi semakin hari semakin didukung untuk bisa menjadi pemimpin di bidang politik dan pemerintahan.

\section{Kepemimpinan Politik Perempuan di Eksekutif}

Masa Orde Baru, politik lokal dan keterwakilan anggota DPRD masih terpusat. Semua kebijakan atau aturan harus sesuai dengan keinginan Jakarta sebagai pusat pemerintahan dan politik. Jabatan gubernur, termasuk walikota dan bupati harus merujuk pada kebijakan pusat sehingga tidak ada kepala daerah yang berjenis kelamin perempuan. Tak hanya sampai di situ, semua kepala daerah harus berlatar belakang militer, tidak ada pejabat sipil ditempatkan di daerah, khususnya Sulawesi Utara yang merupakan provinsi yang berada di perbatasan dengan negara lain.

Era reformasi, dengan pola Pemilihan Kepala Daerah secara langsung dapat dikatakan sebagai awal kebangkitan kembali perempuan Provinsi Sulawesi Utara di kancah politik, seperti terpilihnya Marlina MohaSiahaan pada tahun 2001 sebagai Bupati Kabupaten Bolaang Mongondow. Periode pertama Marlina MohaSiahaan, proses pemilihan masih menggunakan sistem pemilihan perwakilan melalui DPRD Kabupaten Bolaang Mongondow (belum terjadi pemekaran wilayah). Dirinya bahkan dipercaya selama dua periode memimpin di daerah tersebut. Proses pemilihan kedua sudah menggunakan pola pemilihan kepala daerah langsung. Selanjutnya Vonny Panambunan sebagai Bupati Kabupaten Minahasa Utara periode 2005-2010, salah satu daerah pemekaran dari Kabupaten Minahasa. Kemudian Vonny Panambunan, pada Pilkada serentak tahap 1 tahun 2015, kembali berjaya dan dilantik kembali menjadi Bupati Minahasa Utara periode 2016-2021 oleh Gubernur Provinsi Sulawesi Utara pada 17 Februari 2016.

Begitu juga di Kota Tomohon, salah satu daerah pemekaran dari Kabupaten Minahasa, terpilih wakil walikota perempuan periode 2005-2010, Syenny Watoelangkouw. Kini Syerly Adelyn Sompotan menjadi Wakil Walikota Kota Tomohon periode 2016-2021 mendampingi walikota incumbent.

Tahun 2008 terpilih Telly Tjangkulung sebagai Bupati Kabupaten Minahasa Tenggara - kabupaten pemekaran dari Kabupaten Minahasa. Kabupaten Minahasa Selatan, Christiany 'Tetty' Paruntu sudah masuk dua periode menjadi bupati di sana. Tahun 2013, Tatong Bara yang diusung Partai Amanat Nasional menjadi Walikota Kota Kotamobagu untuk periode 2013-2018. Kabupaten Kepulauan Talaud juga menghadirkan Bupati termuda di Provinsi Sulawesi Utara yakni Sri Wahyuni Maria Manalip untuk periode 2014-2019. Tahun 2017 bertambah bupati perempuan di Kabupaten Bolaang Mongondow (hasil pemekaran) yakni Yasti Soepredjo untuk periode 2017-2023.

Meski begitu, pada masa Orde Lama, perempuan Minahasa sudah dipercayakan menjadi Walikota di Kota Manado yakni adalah EW Warouw. Informasi yang ada, Waworuntu merupakan walikota perempuan pertama di Indonesia dan menjadi walikota kedua di Kota Manado. Dia memerintah Manado sejak akhir 1949, namun baru diresmikan pada Maret 1950. Perempuan kelahiran 4 Juni 1899 ini menjadi walikota melalui sebuah pemilihan umum (terbatas), namun ia hanya memerintah hingga 29 Maret 1951 saja. (Sjafari, 2012)

Sementara partisipasi perempuan di pemerintahan, tidak kalah majunya. Gubernur Sinyo Harry Sarundajang saat penyampaian LKPJ 2014 di DPRD Provinsi Sulawesi Utara menyatakan bahwa sebanyak 443 birokrat karier perempuan (44\%) di Provinsi Sulawesi Utara. Dengan rincian eselon II sebanyak 11 birokrat perempuan (21\%), 
eselon III sebanyak 104 birokrat perempuan (36\%) dan eselon IV sebanyak 328 birokrat perempuan (44\%). (Beritamanado.com, edisi 6 April 2015). Ada tren kenaikan antara partisipasi perempuan di bidang politik dengan pemerintahan (birokrasi).

\section{Kepemimpinan Politik Perempuan di Legislatif}

Perjuangan Maria Walanda Maramis akhirnya berbuah manis, khususnya di Provinsi Sulawesi Utara. Dengan berbagai faktor-faktor pendukung yang ada, baik faktor sosial budaya, kebijakan politik, maupun agama terutama Kristen dimana antara laki-laki dan perempuan sama derajat di dalam gereja. Kemajuan keikutsertaan perempuan di bidang politik sangat baik berikut tabel tentang kemajuan politik perempuan di bidang politik di tingkat DPR-RI, DPD, dan DPRD Provinsi Sulawesi Utara di era reformasi.

Di ranah legislatif perempuan Provinsi Sulawesi Utara juga bangkit ketika Sus Sualang-Pangemanan dipercaya sebagai Ketua DPRD Minahasa Utara periode 2004-2009, begitu juga Jenny J. Paruntu menjadi Ketua DPRD Kabupaten Minahasa Selatan 2009-2014. Sebelumnya di DPRD Provinsi Sulawesi Utara, Pandeiroth-Roeroe menjadi Wakil Ketua DPRD periode tahun 1999-2004, bahkan Meiva Lintang, STh menjadi Ketua DPRD Provinsi Sulawesi Utara periode 2009-2014.

Kemajuan politik perempuan Provinsi Sulawesi Utara tidak hanya terjadi di tataran legislatif daerah tapi juga di tingkat nasional. Ada Yasti Suprejo Mokoginta, perempuan pertama di Indonesia yang menjadi ketua Komisi di Senayan. Yasti yang dikenal sebagai sosok perempuan energik ini bisa membuktikan kiprahnya dengan menjadi ketua Komisi V DPR-RI. Posisi yang banyak diidamkan oleh 560 anggota DPR RI yang mayoritas laki-laki.

Keterwakilan perempuan di di DPR-RI tidak secemerlang di DPD-RI. Periode 1999-2004 dan 20042009 tidak ada satupun legislator perempuan di Senayan. Hal itu terjadi karena ketentuan keterpilihan legislator sangat ditentukan oleh nomor urut bukan suara terbanyak.

Era itu semua partai politik, apalagi legislator pusat (DPR-RI) didominasi oleh kaum pria. Periode 2009-2014 perempuan sudah mulai diperhitungkan, Partai Amanat Nasional (PAN) dapil Provinsi Sulawesi Utara dengan sangat percaya diri mencalonkan Dra. Yasti Suprejo Mokoginta pada urut satu dan dirinya berhasil ke Senayan. Vanda Sarundajang dari PDIP pada periode 2009-2014 juga berhasil menjadi wakil rakyat di Senayan dan pada periode 2014-2019 terpilih kembali menjadi wakil rakyat.

DPD-RI, sejak kelahirannya pada tahun 2004, Provinsi Provinsi Sulawesi Utara dengan 4 anggotanya, selalu menyertakan dua anggota perempuan. Periode 2004-2009 terpilih Aryanthi Baramuli, Dra. Sintje Sondakh-Mandey, Marhanny V. Pua, dan F. Mokoginta. Periode 2009-2014, keterwakilan perempuan hanya tertinggal Aryanthi Baramuli bersama Marhanny V.
Pua, F. Tinggogoy, dan Drs. Alvius Lomban, sedangkan Dra. Sintje Sondakh-Mandey pada akhir periode menggantikan Tinggogoy yang meninggal dunia tahun 2013. Periode 2014-2019, keterwakilan perempuan dan pria kembali seimbang dengan terpilihnya Aryanthi Baramuli, Dr. Maya Rumantir, Fabian Sarundajang, dan Benny Rhamdani.

Kepemimpinan politik perempuan di DPRD Kota/ Kabupaten se-Provinsi Sulawesi Utara juga cukup baik. Meski begitu, ada juga kabupaten/kota yang angka legislatornya cukup rendah. DPRD Kota Tomohon berhasil menjadi teratas untuk legislator perempuan yakni sebanyak 7 orang atau $35 \%$ dari 20 jumlah keseluruhan legislator di sana. Posisi kedua, Kota Manado sebagai ibukota Provinsi Sulawesi Utara yakni sebanyak 13 legislator perempuan atau 32,5\% dari 40 jumlah keseluruhan legislator. Posisi berikut adalah Kabupaten Minahasa sebanyak 11 legislator perempuan atau 31,4\% dari 35 jumlah keseluruhan legislator di sana.

Tabel 2. Keterwakilan Legislator Perempuan di DPRD Kabupaten/Kota se-Provinsi Sulawesi Utara periode 2014-2019

\begin{tabular}{cllll}
\hline No. & \multicolumn{1}{c}{ Kota/Kabupaten } & Perempuan & Laki-laki & Jumlah \\
\hline 1. & Kota Manado & $13(32,5$ & $27(67,5 \%)$ & 40 \\
2. & Kota Bitung & $6(20 \%)$ & $24(80 \%)$ & 30 \\
3. & Kota Tomohon & $7(35 \%)$ & $13(65 \%)$ & 20 \\
4. & Kota Kotamobagu & $3(10 \%)$ & $22(90 \%)$ & 25 \\
5. & Kabupaten Minahasa & $11(31,4 \%)$ & $24(68,6 \%)$ & 35 \\
6. & Kabupaten Minahasa & $6(20 \%)$ & $24(80 \%)$ & 30 \\
& Utara & & & \\
7. & Kabupaten Minahasa & $6(20 \%)$ & $24(80 \%)$ & 30 \\
& Selatan & & & \\
8. & Kabupaten Minahasa & $6(24 \%)$ & $19(76 \%)$ & 25 \\
& Tenggara & & & \\
9. & Kabupaten Bolaang & $1(3,3 \%)$ & $29(96,6 \%)$ & 30 \\
Mongondow & & & \\
10. & Kabupaten Bolmut & $2(10 \%)$ & $18(90 \%)$ & 20 \\
11. & Kabupaten Bolsel & $3(15 \%)$ & $17(85 \%)$ & 20 \\
12. Kabupaten Boltim & $1(5 \%)$ & $19(95 \%)$ & 20 \\
13. Kepulauan Sangihe & $6(24 \%)$ & $19(76 \%)$ & 25 \\
14. Kepulauan Talaud & $1(5 \%)$ & $19(95 \%)$ & 20 \\
15 & Siau Tagulandang & $7(35 \%)$ & $13(65 \%)$ & 20 \\
& Biaro & 79 & 311 & 390 \\
\hline & & & \\
\hline
\end{tabular}

Sumber: diolah peneliti dari KPU Provinsi Sulut

Ada beberapa alasan yang dikemukakan legislator perempuan ketika masuk mencalonkan diri menjadi legislator di DPRD Sulawesi Utara, yaitu alasan partai politik, pribadi, keluarga, dan aturan. Menurut mereka, dengan adanya aturan minimal 30 persen keterlibatan perempuan dalam daftar calon sementara (DCS) dan daftar calon tetap (DCT), peluang perempuan semakin besar. Apalagi perempuan tersebut punya hubungan tertentu dengan partai politik, jalan tersebut semakin mulus bagi mereka. Perpaduan hal tersebut sangat mendukung perempuan sehingga menjadi calon legislator bahkan akhirnya berhasil menjadi legislator. Faktor-faktor tadi ditambah faktor sosial, budaya, dan agama yang 
mendukung keterlibatan perempuan dalam dunia politik membuktikan angka keterwakilan politik perempuan di Sulawesi Utara cukup tinggi.

Perempuan yang menjadi legislator di Provinsi Sulawesi Utara dari lima daerah pemilihan yang berbeda menyatakan tidak mengalami kendala budaya maupun sosial ketika mereka menjadi legislator. Dalam aktivitasnya menjadi legislator juga tidak ada kendala, ketika berbicara di sidang-sidang maupun rapat-rapat dengan legislator laki-laki guna menjalankan tugas dan fungsi di DPRD Provinsi Sulawesi Utara. Meski harus diakui, ada faktor klasik secara struktural sebagai legislator di DPRD, yang harus mengikuti aturan fraksi yang merupakan perpanjangan tangan dari partai politik.

\section{SIMPULAN}

Kuantitas dari partisipasi perempuan di bidang politik dan pemerintahan di Provinsi Sulawesi Utara sudah memadai. Secara angka Sulawesi Utara juga cukup menonjol jika dibandingkan secara nasional dengan provinsi-provinsi lainnya di Indonesia. Naiknya angka keterlibatan perempuan itu karena didukung oleh faktor sosial budaya termasuk agama bahkan keberpihakan undang-undang pada partisipasi perempuan di politik dan pemerintahan. Apalagi calon legislator perempuan yang memiliki kedekatan khusus dengan pimpinan partai politik dan penguasa.

Meski begitu, para legislator perempuan masih mengalami kendala klasik ketika menjadi legislator yakni harus mengikuti aturan fraksi. Fraksilah yang menentukan keterlibatan legislator dalam menjalankan tugas dan fungsinya sebagai anggota DPRD di Provinsi Sulawesi Utara. Dalam prakteknya di DPRD, satu legislator perempuan yang menjadi ketua fraksi. Dua legislator perempuan dipercaya menjadi ketua Komisi yang strategis yakni Komisi II Bidang Ekonomi dan Keuangan dan Komisi III Bidang Pembangunan dan Infrastruktur. Badan Anggaran dan Badan Kehormatan, masing-masing diketuai oleh legislator perempuan.

\section{DAFTAR PUSTAKA}

Alfian, M.A. (2018). Wawasan Kepemimpinan Politik Perbincangan Kepemimpinan di Ranah Kekuasaan (Edisi Baru). Bekasi: Penjuru Ilmu.

Andriana, N., Siregar, S.N., Haris, S., Yanuarti, S., Budiatri, A.P. dan Amalia, L.S. (2012) Perempuan, Partai Politik, dan Parlemen: Studi Kinerja Anggota LegislatifPerempuan di TingkatLokal: Perempuan, Partai Politik, dan Parlemen Indonesia: Suatu Analisis. Jakarta. Penerbit: PT. Gading Inti Prima dan Pusat Penelitian Politik, LIPI.
Cresswell, J.W. (2015). Penelitian Kualitatif \& Desain Riset Memilih di antra Lima Pendekatan (Edisi Indonesia). Yogyakarta: Pustaka Pelajar.

Farida, I. (2013). Rekruitmen, Seleksi, Pendidikan dan Pelatihan Birokrat Perempuan dalam meningkatkan pelayanan public di Pemerintahan Kota Bandar Lampung. Sosiohumaiora, Vol.15 (1): 55-63

Fakih, M. (2010). Analisis Gender dan Tranformasi Sosial. Yogyakarta: Pustaka Pelajar.

Hulwati. (2012) Perempuan Dalam Wacana Politik Islam. Jurnal Ilmiah Kajian Gender. Vol. 2 (1): 61-76

Kemen PP dan PA. (2016). Pembangunan Manusia Berbasis Gender 2016. Jakarta. Kementerian Pemberdayaan Perempuan dan Perlindungan Anak dengan Badan Pusat Statistik.

Kriyantono, R. (2010). Teknik Praktis Riset Komunikasi (Disertai Contoh Praktis Media, Public Relations Advertising, Komunikasi Organisasi, Komunikasi Pemasaran. Jakarta: Kencana Prenada Media Group.

Mujahidin, A.M. (2014). Panduan Penelitian Praktis untuk Menyusun Skripsi, Tesis, dan Disertasi. Bandung: Alfabeta.

Mulyana, D. (2010). Metodelogi Penelitian Kualitatif. Bandung: PT Remaja Rosdakarya.

Mosse, J.C. (2010). Gender dan Pembangunan. Yogyakarta: Pustaka Pelajar.

Sinulingga, R. (2006). Gender Ditinjau dari Sudut Pandang Agama Kristen. Jurnal Wawasan. Vol. 12 (1): 47-53.

Sulistyowati, I. (ed). (2006). Perempuan dan Hukum, Menuju Hukum yang Berperspektif Kesetaraan dan Keadilan. Jakarta: Yayasan Pustaka Obor Indonesia.

Wahid, U. (2014). Otonomi Daeran dan Komunikasi Politik Perempuan (Analisis Gramcian Kandidat Perempuan Parlemen Provinsi DKI Jakarta Tahun 2009). Sosiohumaniora. Vol. 16 (1) 2014 : 29-45.

Widayani, N.M.D. dan Hartati, S. (2014). Kesetaraan dan Keadilan Gender dalam Pandangan Perempuan Bali: Studi Fenomenologis Terhadap Penulis Perempuan Bali. Jurnal Psikologi, UNDIP, Vol. 13 (2) 149-162.

Ini Data Partisipasi Perempuan Sulut di Politik dan Birokrat. https://webcache.googleusercontent. com/search?q=cache:Ggb6ykDNuwUJ:https:// beritamanado.com/ini-data-partisipasiperempuan-sulut-di-politik-dan-birokrasi/ $+\& c d=$ $1 \& \mathrm{hl}=\mathrm{id} \& \mathrm{ct}=\mathrm{clnk} \& \mathrm{gl}=\mathrm{id}[19 / 3 / 18]$ 